\title{
Students' Perception toward Schema Theory That Used In Reading Class (A Study on the Fifth Semester Students of English Education Study Program of FKIP UNIB in Academic Year 2010/2011)
}

\author{
Risma Nurandini \\ Rudi Afriazi \\ Mulyadi \\ English Education Study Program \\ Department of Languages and Arts \\ Faculty of Teachers Training and Education of Bengkulu University \\ Bengkulu City, Indonesia
}

\begin{abstract}
The objectives of this research are to identify the perception toward schema theory that used in reading class on the fifth semester students of English Education Study Program of FKIP UNIB in academic year 2010/2011. The population of this research was the fifth semester students of English Education Program of FKIP UNIB in academic year 2010/2011. The population of this study was the whole fifth semester students of English Study Program of Bengkulu University for academic year 2010 - 2011 which consist of 38 students. The sample of this study used total sampling technique. This study was a descriptive study. The instrument of this study was questionnaire. The questionnaire consists of 25 items that purpose to measure students' perception toward schema theory. The result of this research show that the schema theory had 86,50\% positive perception, $12,30 \%$ neutral perception and 1,20\% negative perception. It displayed that the respondents had high positive perception toward schema theory. It means that most of the students agree with the application of schema theory as a learning style in the fifth semester students of English Education Program of FKIP UNIB in academic year 2010/2011.
\end{abstract}

\begin{abstract}
Abstrak: Tujuan dari penelitian ini adalah untuk mengetahui persepsi siswa terhadap teori skema yag di gunakan dalam kelas membaca pada mahasiswa semester lima program studi bahasa Inggris, Universitas Bengkulu tahun ajaran 2010/2011. Populasi penelitian ini adalah mahasiswa semester lima program studi bahasa Inggris FKIP Universitas Bengkulu Tahun Ajaran 2010/2011 yang terdiri dari 38 mahasiswa. Sampel dari penelitian ini menggunakan teknik sampel total atau keseluruhan. Penelitian ini adalah penelitian deskriptif. Instrumen penelitian ini menggunakan kuisioner. Kuisioner yang digunakan terdiri dari 25 item yang bertujuan mengukur persepsi mahasiswa terhadap teori skema yang digunakan dalam kelas membaca. Hasil dari penelitian ini memperlihatkan bahwa teori skema mendapat 86,50\% persepsi positif, 12,30\% persepsi netral dan 1,20\% persepsi negatif. Ini menunjukan bahwa responden memilik persepsi positif yang tinggi terhadap teori skema. Ini berarti rata - rata dari mahasiswa setuju dengan pengaplikasian teori skema sebagai teknik belajar pada mahasiswa semester lima program studi bahasa Inggris Universitas Bengkulu tahun ajaran 2010/2011.
\end{abstract}

\section{Introduction}

In intensive reading, the schema theory stresses the importance of background knowledge in language comprehension. Background knowledge is the small proportion of the subject that has already 
known by a person. When readers have some knowledge of the topic, it becomes easier to understand for them the passage (Nunan, 1991).

Schema Theory is chosen to solve the students' problem in understand reading text based on some reasons. Schema theory is vital in developing comprehension in reading. When the students access prior knowledge, their comprehension ability is so much greater than it would be without any prior information or motivation to read. When schema is activated, it involves the relationship between the different parts of knowledge with understanding the text.

Generally, reading class on English education study program of FKIP UNIB taught by using schema theory, teachers taught them the material by using content schema as basic theory, which pre-reading, while reading and after reading were application of content schema. Even though the teacher applied schema theory in reading class, we still found that students had some difficulties in comprehension the text. It proved by almost of students get standard mark on reading. According to the fifth semester students got $25 \% \mathrm{C}$ and D marks. Their mark showed us that almost of them didn't master reading material. Considering student's problem, a further investigation of what students' perceptions if the schema theory applied by lecture in teaching reading is needed. The researcher takes the data at fifth semester students of English Study Program of FKIP UNIB because the lectures use schema theory in teaching reading class.

According to schema theory, comprehending a text is an interactive process between the reader's background knowledge and the text. Efficient comprehension needs the ability to relate the textual material to one's own knowledge. As the opening quote from Anderson et al. points out, "Every act of comprehension involves one's knowledge of the world as well" (Anderson et al. 1977:369).Based on schema theory readers' schema can be classified into three types: language schema, content schema and form schema.

In this study, the researcher attempted to collect students' perception toward schema theory that used in reading class and identify the perceptions of the fifth semester students of English Education Study Program of FKIP UNIB in academic year of 2010/2011. The result of the study can be used as reference and consideration for headmaster, teacher, and students. For headmaster, the study is used to make 
decision for teacher, such as follow the training. For teacher, the study is used to improve their teaching style or technique,

\section{Definition of perception.}

Perception is a psychological process; according to Gregorc (2001), perception refers to how the brain organizes and interprets sensory information. Until fairly recently perception was considered by the school of psychology called behaviorism to be largely a passive and inevitable response to stimuli. And then, Hornby (2000) argue perception is the way you notice things, especially with the senses.

According to Elliot et al (2000) in Delva (2010), perception is the giving of meaning to the discrete, meaningless stimuli that initially arouse awareness. The meaning that an individual gives to any stimulus depends upon the manner in which that person patterns it. On the other word, perception is the processes by which we receive ad interpret information from the world around us.

According to George (2001), there are three types of perception; detection, recognition, discrimination. Detection refers to whether people can sense that they are being stimulated by some forms of energy. and for the students, the study can use one of their strategies to improve their reading ability.

For example, a light may be so dim they are barely detecting its presence. Recognition means being able to identify as well as detect a particular pattern of stimulation. Discrimination means being able to perceive one pattern of stimulation as different form another For example, a person may hear slight difference between two similar musical tones.

\section{Schema theory in reading material}

According to schema theory, comprehending a text is an interactive process between the reader's background knowledge and the text. Efficient comprehension needs the ability to relate the textual material to one's own knowledge. As the opening quote from Anderson et al. points out, "Every act of comprehension involves one's knowledge of the world as well" (Anderson et al. 1977:369). The process of interpretation is guided by the principles that every input is mapped against some existing schema and that all aspects of that schema must be compatible with the input information. This principle results in two basic models of 
information processing, called bottom up

\section{Methodology}

This study is descriptive study. According to Sukardi (2008), descriptive research is research method which effort to describe an interpret the object based on the fact. The population of this study was the whole fifth semester students of English Study Program of Bengkulu University for academic year 2010 - 2011 which consist of 38 students. The researcher chose this population because the fifth semester students have taken reading class I, II, III and extensive reading. The lecture taught them by using schema theory. The sample of this study used total sampling technique.

The instrument of this study was questionnaire. Questionnaire is a number of written question that will be used to get information from the respondents (report about himself or herself), or other things he knows (Arikunto, 2002). and

top down

processing.

The instrument in this research is questionnaire, it is used to know about students' perception toward schema theory that used in reading class. Five scales, known as Likert Scale, applied in this questionnaire. Each item offer five alternative options and each option has different values. The questionnaire will be tested to measure their validity by $\mathrm{T}$ test and reliability by Alpha Cronbach using SPSS tool.

\section{Finding and Discussion}

The results of this study shows that $29,70 \%$ respondents had an extremely positive perception toward the application of schema theory. While $0,00 \%$ had an extremely negative perception. Further details about the distribution of the data can be seen on the following table 3a Table 3a. Summary of distribution of students' perception.

\begin{tabular}{|ll|l|l|}
\hline Category Aspect & Frequency & Percentages & Total Percentages \\
\hline SA/Extremely Positive & 282 & $29,70 \%$ & $86,50 \%$ \\
\hline A/Positive & 540 & $56,80 \%$ & \\
\hline
\end{tabular}




\begin{tabular}{|c|l|l|l|}
\hline U/Neutral & 117 & $12,30 \%$ & $12,30 \%$ \\
\hline D/Negative & 11 & $1,20 \%$ & $1,20 \%$ \\
\cline { 1 - 2 } SD/Extremely Negative & 0 & $0,00 \%$ & \\
\hline Total & $\mathbf{9 5 0}$ & $\mathbf{1 0 0 \%}$ & $\mathbf{1 0 0 \%}$ \\
\hline
\end{tabular}

Based on the data, s tudents' perception (combination of extremely positive and positive responds) toward schema theory as learning style in reading class was $86,50 \%$. The number was far much higher than the negative one (combination of extremely negative and negative responds) which was only $1,20 \%$. It means that the schema theory was one of the interesting learning styles in reading class.

The researcher found that $84,2 \%$ of the respondents had positive perception for item one. In contrast the other 15,8\% respondents had negative perception. It proves that the students have high motivation in reading text. Item two is about the students' ability to predict about general description of text. In this item the students have $86,9 \%$ positive perception. It means that the students can use their background knowledge to make prediction about text. Item three is about students' mentality to get ready in reading text. This item takes $76,3 \%$ positive perception of respondents.

As it can be seen from the chart before, positive perception is dominant selection of all the respondents. The researcher found that $29,7 \%$ of respondents had strongly agree perception and 56,8\% for agree perception, it means $86,5 \%$ of the respondents had positive perception, it proved that most of the respondents agree with the application of schema theory as a learning style.

Based on the research result, it was found that there are some facts that schema theory held good perception on the students. Item number 1, 2, 3, 4, 5, 6, 7, and 22 showed us how schema theory works to activate students' background knowledge. Schema theory used to motivate students and lead them to make some predictions about what are they going to face in reading text. This statement reinforced by Rumelhart (1980) with good background knowledge schema, readers would also 
have very good prediction.

In this case the students should be able to define their background knowledge that suitable with the given text. The teacher should have good way to activate their background knowledge. If they were able to use their background knowledge it will make them know what things that they are going to read. Teachers can help students to establish specific content schema through providing background knowledge for students to predict correctly. The statement was supported by Rumellhart (1980) who stated that content schema can help reader to predict and choose information, to evaluate the text, rewrite the text with own words and the other skills. Which is in this research they had high positive perception, displayed us how they understand and comprehend the reading material.

From the result of this study, the researcher finds out that the students get many advantages from the applying of schema theory as a learning style. According to Rumelhart in Liu Yu Hui (2010), schema theory especially content schema offer to the students' abilities in two aspects: one is situation of schema connected with reading material; the other is background knowledge schema previously possessed by readers and in this research almost of them good perception, it proved that they are able in that aspects.

In this research we also found negative perception, it proved that some of them were not able in some aspects. They could not understand the text perfectly. Rumelhart(1980) proposed three possible reasons why readers cannot understand a text: first, readers lack proper schema. Under this condition, readers cannot understand the meaning contained in the text at all. Second, readers may possess adequate schema, but the author does not provide enough clues to activate the schema. Therefore, readers still cannot get the meaning. If adequate clue is provided, readers can understand the text. Third, readers interpret the text in a consistent way but deviate from the author's intention. Under this condition, readers seem to understand the text but misunderstand the author's intention or they can't master the abilities they have to but in this research the percentages of negative perception is too low $1,2 \%$ and $12,3 \%$ for uncertain perception.

The experts believe that language schema, content schema and form schema are all very important to develop students' reading ability. When emphasizing 
imparting language knowledge, teachers are suggested to activate content schema in students' mind and help them to establish English form schema to improve students' reading ability, and lay a solid foundation for writing ability.

Becoming a fluent reader involves finding connections to one's own life and making new information part of one's own knowledge. The development of principled flexible skills that can be applied to different reading tasks is one of the most effective things from a reading class. Learners as well as educators can better understand what messages are in a text by examining it with a number of approaches. Schema theory offers insight on the way knowledge is constructed but is far from a complete unveiling of the mysterious process of reading. According to Rumelhart (1977) published Towards an Interactive Model of Reading, which holds that in fact reading process is a complicated "interaction" process of many types of language knowledge, including letters,

\section{Conclussion}

It could be concluded from the result the answer of "What is students' perception toward schema theory in reading?" In this research, the researcher found that the students have positive perception toward words, syntactic patterns and semantic meaning etc., that is, interaction of direct and implicit information; language processing interacts at different levels. This model theory forms the basis of schema Theory.

As we can see from the appendices, the list of interview questions used to know about some information that the researcher cannot get from the questionnaire, and the answers of those questions reinforce their perception toward schema theory. It proved that their answers for the questionnaire are purely from their understanding about schema theory.

So, in this research it displayed that schema theory is suitable with the students as learning style and interactive models as a reading model can applied as a teaching reading style. It proved by their high positive perception toward schema theory.

schema theory. This statement could also explain that the students agree that schema theory used as teaching and learning style. The result reinforced by some researches, it proved that schema theory gave significant effects for students. Schema theory can 
improve their ability in reading comprehension.

Based on theory of content schema from Rumelhart and the result of the research, background knowledge schema

\section{REFERENCES}

Abisamra, Nada Salem. 2001. Teaching Second Language Reading From An Interactive Perspective at http://www.nadasisland.com/reading/. Monday 21 June $201003.00 \mathrm{pm}$.

Anderson, Richard $\mathrm{C}$ and Pearson, $\mathrm{P}$ David. 1987. A Schema Theoretic View of Basic Processes in Reading Comprehension. Cambridge:

Cambridge University Press.

Arikunto,S. 1998. Prosedur Penelitian

Suatu Pendekatan Praktek. Jakarta. Rineka Cipta.

Brow, George 2002. Psychology Guide

Perception.

http://www.a2zpsychology.com/PSYC HOLOGY_GUIDEPercepton.html

Sunday, 16 June 2010, at $04.00 \mathrm{pm}$.

Carrel, Patricia L and Eisterhold, Joan C.

1987. Schema Theory and ESL Reading Pedagogy. Cambridge:

Cambridge University Press.

Carrel, Patricia L, et al. 1986. Interactive Approaches to Second Language previously possessed by readers and situation schema connected with reading material. A good background knowledge and situation can affect directly the degree of reading comprehension.

Reading. Cambridge: Cambridge University.

Casanave, Christine Pearson. 1985. Strategies for Readers (A Reading/Communication Text for Students of ESL).California: Prentice Hall Regents.

Elliot, Stephen et al. 2000. Educational Psychology: Effective Teaching and Learning. United States: The McGrawHill Companies, Inc.

Evaliani, Dessy. 2001. The Effect of Schema Theory Toward the Students Reading Comprehension at the first Year of SMKN 3 Bengkulu Academic Year 2001/2002. Bengkulu University: Unpublished Thesis.

Goodman, Keneath.1987. The Reading Process. In P.L.Carrell, J.Devine \& D.E.Heskey (Eds), Interactive approach to Second Language Reading. Cambridge: Cambridge University Press.

Gregorc, Anthony. 2001. Introduction to 
Perception.

http://www1.sapdesignguild.org/resour ches/optical_illusions/intro_definition.h

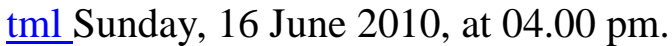

Hui, Liu Yu. 2010. Application of Schema Theory in Teaching College English Reading. $\quad$ http://www.cscanada.net/ Canadian Social Science Monday 21 June 201003.00 pm.

Hornby, A.s. 2005. Oxford Dictionary of English. 7th Edition. New York: Oxford University Press.

Iranian Language Institute Teaching Journal.2005. Vol. 1 no 1 and 2. Iranian Language Institute. I6 June 2010 at $04.00 \mathrm{pm}$.

Nunan. D. 1991. Language Teaching Methodology. Hertfordshire : Prentice Hall International. Sudjono, Anas. 2005. Pengantar Statistik Pendidikan. Jakarta: PT. Raja Grafindo Persada.

Sugiyono. 2008. Metodologi Penelitian Pendidikan. Bandung: Alfabeta.

Sukardi. 2008. Metodologi Penelitian Pendidikan: Kompetensi dan Praktiknya. Jakarta: Bumi Aksara.

Ur, Penny. 1996. A Course in Language Teaching: Practice and Theory. London: Cambridge University Press.

Widiarti, Deni. 2008. The Effect of "Schema Development Technique" in
Improving Students' Reading Ability (A Study on fourth Semester Students of English Study Program of FKIP UNIB in Academic Year 2007-2008). University of Bengkulu: Unpublished Thesis. 